\title{
JOAN AFFERICA
}

\section{Sigizmund Natanovich Valk, 1887-1975}

Professor Valk, the distinguished dean of Leningrad historians, died on February 5 of 1975 at the age of eighty-seven. To review his career is to recall the splendid historical trairing provided by the University of St. Petersburg on the eve of World War I and to retrace the course of Soviet historical study, many of its principal aims, priorities, methods, and achievements. Professor Valk's scholarly legacy includes over two hundred printed works ; generations of students who benefited from his erudition. prodigious memory, and generous spirit; and a lasting contribution to the development of Soviet archival science and source study.

Born in Wilno (Vilnius), the son of a pharmacy owner, he left home as a young man to make his career in St. Petersburg. (His mother and sisters were to remain in the city after the Russian Revolution, the sisters perishing during the German occupation in World War II.) Valk qualified for admission to the historical-philological faculty of Petersburg University. There he shared the stimulating environment that nurtured leaders of historical study for decades to come-I. M. Grevs, A. E. Presniakov, M. D. Priselkov, E. V. Tarle, B. D. Grekov, to mention but a few. The decisive intellectual influence of those university years, however, both on the direction of Valk's later scholarship and the refinement of those skills essential to its most exacting performance, belonged to A. S. Lappo-Danilevskii. As founder in 1903 of the Permanent Historical Commission which undertook source publication alongside the older Archeographic Commission, Professor Lappo-Danilevskii was elaborating the theoretical aspects of the task in the course of preparing the Historical Commission's outstanding achievement, the edition of archival documents from the College of Economy. Valk recalled with professional admiration and warm personal feeling at various points in his long life the significance of this work, the meticulous standards of its inspirer, and the sterling merits of the teacher.

Unable to establish himself in government service upon graduation in 1913, Valk accepted a position with the Granat Encyclopedia. His articles for

1. Chronological lists of his publications through 1972 are found in Issledovaniia po otechestzennomu istochnikovedeniiu. Sbornik statei, posviashchennykh 75-letiiu professora S. N. Valka (Moscow-Leningrad: "Nauka," 1964), pp. 504-13 and in Arkheograficheskii ezhegodnik za 1972, pp. 291-92, neither of which appears to be complete. His most recent work will appear posthumously in Trudy Otdela drevnerusskoi literatury, vol. 30. 
that publication in the next years already suggest the remarkable thematic and chronological breadth that later characterized his historical research. At the same time he made modest contributions, mostly reviews, to S. P. Mel'gunov's Golos minuvshego. His real development as archeographer and historian, however, followed the October Revolution.

In mid-1918 Valk joined the staff of the new Petrograd HistoricalRevolutionary Archive which spent its first days gathering and carting to the Senate building documents scattered about the city by the hazards of revolution. For almost fifty-seven years he was to remain with the Archive and then with the research institution formed in 1926 from the merger of the Archeographic and Permanent Historical Commissions which, after several changes of title, became in 1936 the Leningrad branch of the Institute of History of the Academy of Sciences. (In 1932 Valk was named senior research associate of the Historical-Archeographic Institute, as it was then called.)

The Petrograd Historical-Revolutionary Archive occupied a special place in the design for a highly centralized Soviet state archival system. It was deliberately created as a repository for the records of various police, gendarme, and investigatory units of the tsarist government. In 1918 it began with the archive of the Department of Police (1881-1917), which included as well materials of the Third Section, the chancery of the Ministry of Police (18001816), the special chancery of the Ministry of Internal Affairs, and various special commissions. Added in 1919 were, among other materials, the complete records from the eighteenth century to 1917 of the chancery of the administrative commandant of the Peter and Paul Fortress and Alexis ravelin. The Archive contained in addition an exceptional collection of illegal publications printed in Russia and abroad. It thus became a unique center for study of the revolutionary movement in the nineteenth and early twentieth centuries. The projected work of the Archive itself as well as the overlapping attentions of other new organizations vying to exploit this extraordinary resource-the Commission for the Study of the History of the Russian Communist Party and October Revolution (Istpart) and the Lenin Institute, for examplewould assure the intense and uninterrupted activity of the archival staff until transfer of the police materials in 1924 to Moscow where today they form part of the Central State Archive of the October Revolution.

To be a member of the archival staff was to be at the center of the historical activity favored by the new government. Valk had the occasion not only to be among the first students to explore the documentary record of the most. dramatic episodes of the revolutionary past but to work with its living representatives, men like O. V. Aptekman, former populist, member of Black Partition, and later Social Democrat; and Lev Deich, who turned from populism to help found, with Plekhanov, the Liberation of Labor group. In 
1920, toward the end of the Civil War, the work of Valk and his colleagues began to appear in the rash of new publications that competed in the early twenties to acquaint professionals and the general public with aspects of the victorious revolutionary tradition, such as Dela $i d n i$, Kniga i revoliutsiia, Krasnaia letopis', Krasnyi arkhiv, Proletarskaia revoliutsiia and Katorga $i$ ssylka. A survey of the Archive's activities in its first decade reveals that Valk played an important role in elucidating principles for the arrangement and description of the newly accessible materials, making them available to scholars and publicists, popularizing their contents by means of public exhibits and lectures, and training young archival workers.

Valk's publications in this period concerned two interdependent subjects, revolutionary history and archival methods. Most frequently in the form of annotated source material, they served to extend factual knowledge, and at the same time they exhibited the results of careful work to develop principles for classifying materials on the revolutionary movement and to set standards for future printing of documents. While a plan for publication had been prepared in the Archive as early as 1918, it could only begin to be implemented during the twenties, and especially under the aegis of the Petrograd Bureau of Istpart, headed by V. I. Nevskii, which sponsored extensive editions of revolutionary materials supplied from this Archive. Valk's particular interests, to judge by the printed record, included the Morozov strike of 1885 (1921), the Petrograd group Workers' Banner (1922, 1924), and the July 1914 disturbances in Petersburg (1924). More important, however, was his work on the history of May Day in Russia. Together with A. A. Shilov he coedited the Pervomaiskaia khrestomatiia and a bibliographical index of four thousand May Day proclamations (1924). He also contributed as one of several editors to a publication of Social Democratic leaflets at the time of the 1905 Revolution (1925).

The results of work with these revolutionary materials informed the papers Valk delivered in 1920 before the First Petrograd Conference of Archivists (published in 1923) and in 1925 before the First Congress of Archivists of the RSFSR (published the same year). His concern with scholarly preparation of source materials may be followed in his critical surveys of Soviet documentary publications and of foreign, especially Polish and German, archival work which appeared in the form of reviews or short articles throughout the twenties and early thirties. Valk's contribution to the formulation of rules for the publication of source materials drew on both the current work of the Archive and the legacy of his mentor, Professor LappoDanilevskii, whose rules for publishing the documents of the College of Economy, issued posthumously in 1922, recapitulated almost two decades of painstaking work on source publication. Valk considered Lappo-Danilevskii's rules 
the summit of prerevolutionary archeographical literature and as such the bridge from the experience of the latter to the new tasks and subject matter of Soviet archeography. They represented, in his view, an indubitable model for all subsequent work on drafting rules for documentary publication.

At the invitation of the Lenin Institute, Valk turned to preparing rules for a proposed Academy edition of the complete works of V. I. Lenin. His draft appeared in 1926. The Academy edition was not completed, but Valk's approach was applied in part to the valuable series, Leninskie sborniki, and some years later to his edition of the Decrees of the October Revolution. A recent textbook issued by the Historical-Archival Institute in Moscow underscores the scholarly importance of the volume of decrees for the development of Soviet archeography.

Again the printed record suggests that while Valk pursued his interest in the working class movement-he directed the edition of a bibliographical guide to Social Democratic leaflets, 1894-1917 (1931) and prepared for publication the leaflets of the Union of Struggle for the Liberation of the Working Class, 1895-97 (1934), under the aegis of the recently merged Marx-Engels-Lenin Institute-he turned as early as 1924 to the study of populism and, more narrowly, to investigation of People's Will. Annually for nine years he published mostly short pieces-documents, articles, reviewsthat conveyed the dramatic experiences of over a dozen major and minor figures in the terrorist movement before and after the assassination of Alexander II in 1881. Whether he took part in the acrimonious debate on the significance of People's Will that rent the scholarly community at the end of the twenties is not certain. In any case his last contribution on this theme for several decades was the major volume of documents which he edited and introduced-Arkhiv "Zemli $i$ voli" $i$ "Narodnoi voli" (1932), one of numerous publications of the All-Union Society of Political Prisoners and Exiles. (Under the same auspices he would help edit three years later the first and only volume of a projected bibliographical guide to the Russian underground and foreign press which dealt with the preceding period, 1831-79.) It is regrettable that Valk published no major monograph on People's Will, given the years he devoted to the subject; characteristically, however, the voluminous publication of documents has often taken precedence in Soviet scholarship over monographic formulation of their significance.

Almost two decades of fruitful work established Valk's reputation as one of the principal specialists on sources for the study of the revolutionary movement and one of the most respected authorities on major documentary publications. In the former capacity he contributed to the historians' most important collective effort of the late thirties, the two-volume Istoriia SSSR. His chapter on political reaction during the 1880 s was reworked for the 
second (1949) and third (1954) editions of the volume. His interpretation of various aspects of tsarist internal policy and the social movement from the late 1880s into the early twentieth century appeared in two other versions of Istoriia SSSR $(1951,1959)$ as well as in volumes two and three of Ocherki istorii Leningrada (1956-57). His stature as a pioneer in Soviet source publications may be measured by his editorship in 1933 of the aforementioned Decrees of the October Revolution, issued by the Marx-Engels-Lenin Institute. This major edition, interrupted after the first volume, would be resumed by Valk over twenty years later as Decrees of Soviet Power, published intermittently from 1957 under his editorship. Another gauge of his prominence was his participation in the professionally and politically significant symposium, Twenty-five Years of Historical Study in the USSR (1942), for which he wrote an extensive account of Soviet documentary publications on the history of the USSR in the nineteenth and twentieth centuries.

A list of all Valk's major and minor publications on the revolutionary movement, while reinforcing his claim to an honored place in this area of research, would, however, convey a one-sided picture of his scholarly activities. Valk is no less remembered for his distinguished contributions to the study of earlier periods of Russian history. This second direction of his scholarly efforts, of equal or greater importance than the first, properly begins in the thirties with the reorientation of historical studies which accompanied the discrediting of M. N. Pokrovskii's school. A more traditional organization of historical study would reinstate historical faculties at the universities and reintroduce higher academic degrees. (The doctoral degree was conferred on Valk in 1936.) A return to more traditional periodization and the general atmosphere encouraged scholars to pursue research in earlier historical periods largely neglected in Soviet publications. Valk was no exception. If in the twenties, while developing the new field of revolutionary history, he had managed to publish only an article honoring S. F. Platonov (1922), another concerning the printed archival documents of the College of Economy (1924), and a small number of reviews, he embarked in 1934 on the study of earlier centuries which, with brief interruptions, came gradually to constitute perhaps the principal focus of his scholarly activity. In that year he published an article on eighteenth-century Russian historiography and delivered a paper concerning the genesis and development of feudal society at the Plenum of the State Academy of the History of Material Culture (the former Archeological Society). By 1937 he had returned to the subject matter of Lappo-Danilevskii's rigorous university seminars. In that year he contributed three articles on the diplomatics of private charters and their publication to the journal of the Novgorod Section of the Academy of Sciences, edited by B. D. Grekov, to the new journal Vospomogatel'nye istoricheskie distsipliny, and to Istorik- 
Marksist-all three pieces a foretaste of major work that would yield abundant results after World War II. His scholarly accomplishments in the second half of the thirties were modest, however; he published nothing in 1936 and 1938 and only one article in 1939, on the text of decrees of the October Revolution and the need for their scholarly edition.

The harvest of Valk's long experience in the archives began in the fifth decade of his life. Now a professor at Leningrad University, he brought to fruition years of work in history and the auxiliary historical disciplines. As in the twenties, his work followed two interdependent lines: those of archival science and documentary publications. In 1948 he published the sole monograph of his long career, Sovetskaia arkheografia, a substantial portion of which had already appeared in the symposium Twenty-five Years, and in 1949 he published the important edition, Gramoty Velikogo Novgoroda $i$ Pskova. Like so many other scholars in the period, he did not escape attacks for alleged "bourgeois objectivist positions," these in connection with his article, "Historical Science in Leningrad University for 125 Years," written on the occasion of the University's jubilee in 1948.

For the next twenty-five years Valk would be associated in various editorial capacities, with major documentary publications relating to Russian history, among them the excellent seven-volume edition of Tatishchev's Istoriia rossiiskaia (1962-68) which, with related articles in scholarly journals, engaged his attention at least from 1957. Through his work on Tatishchev, it would appear, he was led to study Russkaia pravda on which source he wrote intermittently from 1957 to 1962 . His name appears on a volume of reports by ministers of internal affairs concerning implementation of the Peasant Reform (1950), the third volume of documents on the Petrashevtsy case (1951), D. I. Mendeleev's archive (1951), the description of A. V. Suvorov's manuscripts (1955), a source volume on the peasant movement, 1796-1825 (1961), and the drafts and memoranda of M. M. Speransky (1961). From the mid-fifties he resumed his editorial association with documentary publications concerning more recent historical periods-two volumes on the general strike of October 1905 (1955), the Soviet decrees mentioned above (from 1957), three volumes of papers from raion soviets of Petrograd in 1917 (1964-66), and two volumes on populism in the 1870s (1964-65). He collaborated in preparing Rules for the Publication of Historical Documents (1955), edited Rules for the Publication of Documents of the Soviet Period (1960), and helped edit the major guide to the Central State Historical Archive in Leningrad (1956).

His editorial work was not confined to documentary publications. It included a substantial number of symposia (sborniki), the themes of which again demonstrated his wide-ranging historical interests. Among the subjects 
treated were the October uprising in Petrograd (1957), economy and class relations in the Russian state from the twelfth to seventeenth centuries (1960), historiography and source study of the history of the USSR (1963), the history of "feudal-serf" Russia (1964), Russian economy and class relations at the end of the nineteenth and beginning of the twentieth century (1964), the city of Lenin in October 1917 and World War II (1964), the St. Petersburg Women's Bestuzhev courses, 1878-1918 (1965, 1973), and Lenin and Russian sociopolitical thought (1969).

His continuing interest in archival science and source study took the form of articles and reviews throughout the period along with a leading role in the symposia Vospomogatel'nye istoricheskie distsipliny and the journal Arkheograficheskii ezhegodnik. In the last decades of his life he was frequently invited to compose obituaries for his teachers, peers and students, his fellow historians, archivists, archeographers. Their contributions, like his own, spanned the entire period of Soviet historical study and beyond: Professor M. D. Priselkov (1941), I. A. Bychkov (1944), L. M. Dobrovol'skii (1963), I. A. Golubtsov (1968), V. A. Petrov (1969). Valk wrote also of the scholarly contributions of B. A. Romanov (1958), B. D. Grekov (1960), I. I. Liubimenko (1960) ; and he joined with his colleagues to honor in Festschriften the profession's leaders: B. D. Grekov (1952), A. M. Pankratova (1958), P. N. Berkov (1966), N. V. Ustiugov (1966), I. I. Smirnov (1967), B. A. Romanov (1971), V. V. Mavrodin (1971), E. V. Tarle (1972), L. V. Cherepnin (1972). And in his turn he received the homage of his colleagues in 1964 on the occasion of his seventy-fifth birthday in the volume fittingly entitled Issledovaniia po otechestvennomu istochnikovedeniiu.

To survey the life's work of a prolific scholar is inevitably to overstress the printed word before the more elusive and perhaps deeper influence of the man himself as teacher and colleague. Professor Valk, whose personal history is so indissolubly bound with the great city in which he forged his distinguished reputation, was known for over half a century not only in the corridors of that city's eminent research institutions but also in its university halls where in the twenties he taught his first course-on sources for studying the revolutionary movement. Few can match the extraordinary contribution he made over the decades as adviser to students and associates, historians, philologists, specialists in the auxiliary historical disciplines. They will remember his unstinting encouragement of their work. They will perhaps have seen his superb small collection of the painters of his youth which included the works of Kuzma Petrov-Vodkin, Konstantin Somov, Marc Chagall, and Martiros Saryan. They will recall his unassuming manner, his reluctance to call attention to himself at public meetings, although he is said to have been capable of biting sarcasm when his interlocutors did not share his dedication 
to scholarly excellence. The portrait in his commemorative volume conveys some distinctive traits associated with the Russian scholarly tradition-the gentle face almost hidden behind the pince-nez and the graying beard, the clothes somewhat awkwardly hung on the small frame, the look of slight discomfort at the camera's attention. A familiar figure in the archives, he exhibited two particularly characteristic attitudes-one of intense concentration as he studied the sources before him, the other of rapid motion as he hurried between them.

The editors of the commemorative symposium praised him as one of the founders of Soviet source study and summarized his contribution in the following manner: "The characteristic trait of his scientific work is the merger of the theoretical elaboration of the problems of source study and archeography with a high mastery of their practical application." The impressive record of his printed works clearly demonstrates certain distinguishing features of Soviet historical writing-the preponderance of collective efforts, the small precise contributions on narrowly defined subjects, the emphasis on. source work and thorough exploration of limited bodies of source materials, the reluctance to risk premature generalizations. Professor Valk stands most significantly, however, among those respected scholars who have labored to establish the highest critical standards in the selection and preparation of documents for publication. His work thus prepares the way for the synthesizing efforts of his colleagues to follow. And for a long time to come, the student who comes upon the archival document forgotten, ignored, or theretofore unsuspected will perhaps find, as did this writer, that Sigizmund Natanovich Valk had been there first. 